\begin{tabular}{ll}
\hline 論 & 説 \\
\hline
\end{tabular}

頭頸部癌の抗癌剤耐性とその克服

斎藤＼cjkstart等・田中 信之・杉本 千鶴・都築 秀明

\title{
Anticancer Drug Resistance and Approaches to Overcoming it in Head and Neck Cancer
}

\author{
Hitoshi Saito, Nobuyuki Tanaka, Chizuru Sugimoto and Hideaki Tsuzuki \\ (Fukui Medical School)
}

The incidence of natural chemoresistance in head and neck cancers was 72 to $79 \%$ (76\% in average), based on estimates obtained from 3 kinds of chemosensitivity tests including the human tumor clonogenic assay, the rapid thymidine incorporation assay, and the ATP assay. The average incidence of sensitivity to anticancer drugs, $24 \%$, was almost the same as the previously reported average efficacy of single drugs, $27 \%$.

Several mechanisms of resistance were discussed and some effective compounds to overcome anticancer resistance were reviewed. One established mechanism of multidrug resistance is elevated expression of P-glycoprotein (Pgp). The expression of Pgp was studied using immunohistochemical techniques in 31 squamous cell carcinomas (SCC) using two monoclonal antibodies, C219 and JSB1. Pgp was detected in $61 \%$ of the samples. In the CDDP resistant cell line, IMC-3/CR, both a decreased influx and increased efflux of CDDP were observed. Cellular glutathione (GSH) level is thought to be another factor in anticancer drug resistance. Therefore, GSH content in 28 malignant head and neck tumors was measured by high-performance liquid chromatography. SCCs contained significantly higher levels of GSH than thyroid papillary carcinomas. Chemosensitivity to CDDP was negatively correlated with cellular GSH content. Some compounds effective in overcoming drug resistance, such as calcium channel blockers, calmodulin inhibitors, cyclosporin derivatives, amphotericin B, DHA, BSO, caffeine, and pentoxifylline were discussed.

Key words : resistance, head and neck cancer, chemosensitivity, P-glycoprotein, glutathione

\section{I＼cjkstart頭頸部癌の抗癌郕感受性と耐性の現状}

副作用の多い抗癌剂を抗癌剂感受性試験によって, 感 受性のある症例にのみ使用しようとする試みは，1977年 頃から脚光を浴びて登場してきた1)。そして頭頸部癌に たいしても次第に行われるようになってきたが，その報 告はまだ少ない。

感受性陽性と臨床相関をみた論文が多いが，反対の陰 性すなわち耐性に変換して，報告を整理してみると，耐
性率は $60 \%^{2)}, 70 \%{ }^{3)}, 72 \sim 8 \%{ }^{4)}, 79 \%{ }^{5)}, 80 \sim 73 \%{ }^{6)}$ と なる。耐性には，自然耐性と獲得耐性とがあるが，以上 の耐性率は，無治療腫瘍細胞を使っているので，自然耐 性と考光られる.すなわち, 今後はこの耐性の克服, あ るいは耐性の少ない薬剤の開発がなければ，有効率の向 上といら壁は打破できないと言える.

抗癌剂感受性試験には, いろいろあるが7われわれが 行ってきた方法での, 感受性と耐性の現状をまず整理し 
てみる。

1) Human Tumor Clonogenic Assay (HTCA)

この方法は, 臨床相関率が高いといら利点があるが, 2 週間以上かかることや評価可能率が低い(47\%) 欠点が あるため，われわれは1984年から1985年まで行い，最近 では行っていない，例数は少ないが，過去の結果を表 1 に示した。原発, 転移を含めた合計での感受性は $24 \%$, すなわち耐性率は76\%であった。

2 ) Rapid Thymidine Incorporation Assay (RTIA) 1986年からはHTCA よりも短期間の 5 日間で結果の でる RTIA 法を用いるようになった．評価率は期待し たほど高くなく，50\%(52/105 症例)であった。感受性 の結果を表 2 に示した. 原発, 転移を含めた合計の感受 性は $21 \%$ ，すなわち耐性率は79\%であった。

\section{3) ATP 法}

1990年末からは，細胞内 ATP 量を指標としたATP 法を用いている. 癌細胞内の ATP 量がその生存性の指 標となることを利用している。ホタルから精製したルシ フェリンとATP とルシフェラーゼ存在下で反応させる と, ATP 量に応じて発光するので, これをルミフォト メーター $(560 \mathrm{~nm})$ で測定する。抗癌剤添加群の ATP 量が対照の $50 \%$ 以下に低下した場合を感受性陽性として いる. この方法は, 簡便で， 3 日間で結果がでて，評価 率も高く，臨床相関もよい評価を得ている6).

1990年12月より1995年12月までに，手術または生検に より得られた，未治療の頭頸部悪性腫瘍 139 症例に用い た。 その結果を表 3 に示した。原発，転移を含めた合計 の感受性は，28\%，すなわち耐性率は72\%であった。

表 1 HTCA 法による頭頸部癌の抗癌剂別感受性

\begin{tabular}{cccccccc}
\hline \hline & BLM & PEP & MMC & CDDP & ADM & 5 -FU & 合計 (\%) \\
\hline 原 発 & $2 / 6$ & $2 / 4$ & $1 / 5$ & $1 / 6$ & $1 / 5$ & $0 / 6$ & $7 / 32(22)$ \\
転 移 & $2 / 3$ & $1 / 4$ & $1 / 3$ & $1 / 3$ & $0 / 3$ & $0 / 3$ & $5 / 19(26)$ \\
\hline 合 計 & $4 / 9$ & $3 / 8$ & $2 / 8$ & $2 / 9$ & $1 / 8$ & $0 / 9$ & $12 / 51(24)$ \\
$(\%)$ & $(44)$ & $(38)$ & $(25)$ & $(22)$ & $(13)$ & $(0)$ &
\end{tabular}

感受性あり検体数 / 総検体数

表 2 RTIA 法による頭頸部癌の抗癌剤感受性

\begin{tabular}{cccccccc}
\hline \hline & BLM & PEP & MMC & CDDP & ADM & 5 -FU & 合計 (\%) \\
\hline 原 発 & $4 / 18$ & $13 / 47$ & $8 / 48$ & $14 / 57$ & $4 / 26$ & $9 / 53$ & $52 / 249(21)$ \\
転 移 & $1 / 6$ & $6 / 18$ & $3 / 16$ & $2 / 15$ & $1 / 7$ & $4 / 21$ & $17 / 83 \quad(20)$ \\
\hline 合 計 & $5 / 24$ & $19 / 65$ & $11 / 64$ & $16 / 72$ & $5 / 33$ & $13 / 74$ & $69 / 332(21)$ \\
$(\%)$ & $(21)$ & $(29)$ & $(17)$ & $(22)$ & $(15)$ & $(18)$ &
\end{tabular}

感受性あり検体数 / 総検体数

表 3 ATP 法による頭頸部扁平上皮癌の抗癌剤感受性

\begin{tabular}{|c|c|c|c|c|c|c|c|c|}
\hline & $5-\mathrm{FU}$ & $\mathrm{ADM}$ & CDDP & PEP & CBDCA & MTX & MMC & 合計（\%) \\
\hline 原 発 & $19 / 63$ & $14 / 56$ & $17 / 63$ & $16 / 63$ & $17 / 61$ & $12 / 50$ & $7 / 56$ & $102 / 412(25)$ \\
\hline 転 移 & $11 / 25$ & $9 / 24$ & $8 / 25$ & $9 / 25$ & $7 / 25$ & $8 / 22$ & $9 / 24$ & $61 / 170 \quad(36)$ \\
\hline $\begin{array}{c}\text { 合 計 } \\
(\%)\end{array}$ & $\begin{array}{c}30 / 88 \\
(34)\end{array}$ & $\begin{array}{c}23 / 80 \\
(29)\end{array}$ & $\begin{array}{c}25 / 88 \\
(28)\end{array}$ & $\begin{array}{c}25 / 88 \\
(28)\end{array}$ & $\begin{array}{c}24 / 86 \\
(28)\end{array}$ & $\begin{array}{c}20 / 72 \\
(28)\end{array}$ & $\begin{array}{c}16 / 80 \\
(20)\end{array}$ & $163 / 582(28)$ \\
\hline
\end{tabular}

感受性あり検体数 / 総検体数 
4 ) 抗癌剤感受性試験の問題点

この試験法は in vitroであるので，感受性を上げょら とすれば，高濃度の抗癌剂と接触させればよいわけであ るが, それでは臨床相関は低くなる。通常, 最高血中濃 度の1/10を使用しているが, やはり検査法の良し悪し は，臨床相関率である。

次に問題は，カットオフ值といって，抗癌剤によって， 癌細胞が何\%死隇すれば，感受性あり，とするかである. 通常 $50 \%$ 以上死隇与れば，有効剤としているが，この\% を変化させれば，当然感受性率も変化する。

5)まとめ

われわれの経験した， 3 種類の感受性検査での, 感受 性陽性率は28～21\%(平均24\%), 逆の自然耐性率は, 72 〜 79\%であった。感受性陽性率は, 過去の単剤での奏功 率 $(13.8 \sim 42.2$, 平均 $27 \%$ ) に活活類似している8).

\section{II 頭頸部癌の抗癌剤耐性機構の分析とその克服}

現在考兄られている抗癌剤に対する耐性機構は以下の 6 項目が考えられている.

（1）細胞内薬剤蓄積量の低下-P-糖蛋白

（2）薬斉の不活化，解毒一グルタチオン
（3）薬剤活性化酵素の低下

(4) 標的酵素の変化

(5) DNA 修復系の充進

(6) アポトーシス耐性

以上の項目について，頭頸部癌を中心に現状を分析し てみる。

1) 細胞内薬剤蓄積量の低下-P-糖蛋白の関与

$\mathrm{P}$-糖蛋白とは, 抗癌凨の多剤耐性の遺伝子 $\operatorname{mdr} 1$ の産 物である9).P-糖蛋白は多剂耐性の中心的役割を担って いるものであり, 細胞膜に存在して膜の透過性 (permeability) に関係するのでこう呼ばれている. その遺伝子 が 7 番染色体の長腕に位置して扣り，プロテインキナー ゼCによって調節され，ATP 依存性に薬剤を細胞外へ 排泄するポンプとして働いている10)(図 1 ).

従来, 頭頸部扁平上皮癌に対する P-糖蛋白の発現率 は低いとされていたが11)，抗体の普及により詳細に検討 がなされてくると，発現率は60〜 61\%であり，意外に耐 性癌が多いことがわかってきた12)〜14). 表 4 に頭頸部扁 平上皮癌に対するわれわれのデータを示した。すなわら， 頭頸部扁平上皮癌31例中， $61 \%$ P-糖蛋白が陽性であ った.

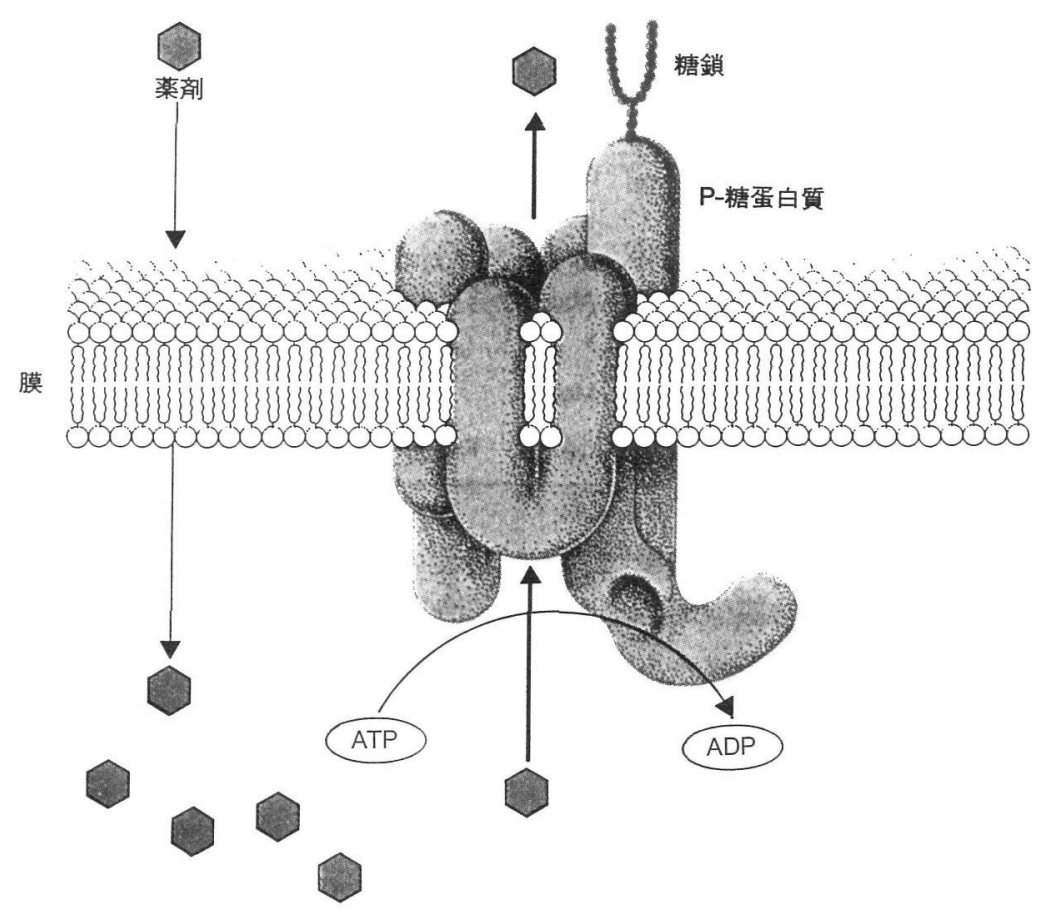

図 1 P-糖蛋白質の構造と機能 
表 4 頭頸部扁平上皮癌に批ける P-糖蛋白の発現状況

\begin{tabular}{|c|c|c|c|c|}
\hline 部 位 & 症例数 & C219*陽性 & JSBI* 陽性 & 陽性合計（\%） \\
\hline 副鼻腔 & 6 & 5 & 4 & $9 / 12(75)$ \\
\hline 口腔咽頭 & 11 & 7 & 6 & $13 / 22(59)$ \\
\hline 喉＼cjkstart頭 & 11 & 5 & 6 & $11 / 22(50)$ \\
\hline 甲状腺** & 2 & 2 & 2 & $4 / 4 \quad(100)$ \\
\hline 皮 虐 & 1 & 0 & 1 & $1 / 2 \quad(50)$ \\
\hline 合 計 & 31 & 19 & 19 & $38 / 62(61)$ \\
\hline
\end{tabular}

多剤耐性といっても，アドリアマイシン (ADM) など のアンスラサイクリン系，エトポシド，マイトマイシン $\mathrm{C}(\mathrm{MMC})$, ビンカアルカロイド，タキソールなどに耐 性であって，頭頸部癌によく使用される，ペプロマイシ ン (PEP)，5-FU，CDDP，などは関係ないといわれてい る.

では，実際の頭頸部癌ではどらであろらか、アドリア マイシンに対する感受性を ATP 法で調べ，同じ癌のP糖蛋白の免疫組織学的発現とを比較したところ， $\chi^{2}$ 検 定にて有意差をもって，P-糖蛋白の発現とアドリアマイ シン耐性とは相関関係がみられた(表 5 ) ${ }^{14)}$. 以上のよう に, 頭頸部癌でも P-糖蛋白が抗癌剤の感受性に関与し ていることが明らかになった。

この $\mathrm{P}$-糖蛋白を標的とした耐性克服の試みには，力 ルシウム拮抗剤(ベラパミル)15), カルモジュリン阻害剤 (クロールプロマジン) ${ }^{16)}$, サイクロスポリン誘導体(サ イクロスポリン A)，など多くの報告がある. ベラパミ ルの臨床治験では, 耐性克服に必要な濃度を得るために 心血管系の副作用を伴ったが，高い有効性が報告されて
いる17)、また，サイクロスポリンAは耐性克服に必要な 濃度で重篤な合併症がないので臨床応用が有望といわれ ている1819).

一方，P-糖蛋白の排出ポンプ機構にはよらないが， 薬剤流入量の低下がアルキル化剤, メソトレキセート (MTX)，CDDP ではいわれている．われわれの樹立し た CDDP 耐性株でも，その細胞内蓄積量の低下を認め たが，排出も充進していた(図 2，3）.

P-糖蛋白によらないこれらの耐性克服には，アンホテ リシンBやドュサヘキサェン酸 (DHA) などがある．前 者は細胞膜のコレステロールと結合して細胞膜透過性を 变化させるとされているが，臨床応用では顕著な効果は みられていない20)。一方，DHA はェイコサペンタェン 酸とともに魚油に特異的な脂肪酸で, 経口投与が可能で 臨床応用が有望といわれている21).

2 ）薬剤の不活化, 解毒一グルタチオン

還元型グルタチオン $(\mathrm{GSH})$ は注とんどの細胞に存在 し, 非蛋白質性 $\mathrm{SH}$ 基の大半を占め, フリーラジカルの 処理にあたっている。また，抗癌剤の CDDP やアルキ

表 5 抗癌剤感受性試験 (ATP 法) と P-糖蛋白の発現 ${ }^{14)}$

\begin{tabular}{|c|c|c|c|c|}
\hline 抗癌㶡感受性 & P-糖蛋白 & $\begin{array}{c}\text { 陽 性 } \\
(\text { 染色 }>50 \%)\end{array}$ & $\begin{array}{c}\text { 陰 性 } \\
(\text { 染色 } \leqq 50 \%)\end{array}$ & 合計 \\
\hline \multirow{2}{*}{$\begin{array}{c}\text { ADM 耐性 } \\
(\text { ATP 残 > } 50 \%)\end{array}$} & $\mathrm{C} 219$ & 24例 (48\%) & 13例 $(26 \%)^{*}$ & 37例 \\
\hline & JSB1 & 27 例 $(54 \%)$ & 10 例 $(20 \%)^{* *}$ & $(74 \%)$ \\
\hline \multirow{2}{*}{$\begin{array}{c}\text { ADM 感受性 } \\
(\mathrm{ATP} \text { 残 } \leqq 50 \%)\end{array}$} & $\mathrm{C} 219$ & 3例 $(6 \%)$ & 10例 (20\%) & 13例 \\
\hline & JSB1 & 4例（ $8 \%)$ & 9例（18\%） & $(26 \%)$ \\
\hline \multirow[t]{2}{*}{ 合計 } & $\mathrm{C} 219$ & 27例 (54\%) & 23例 $(46 \%)$ & 50 例 \\
\hline & JSB1 & 31 例（62\%） & 19例（38\%） & $(100 \%)$ \\
\hline
\end{tabular}




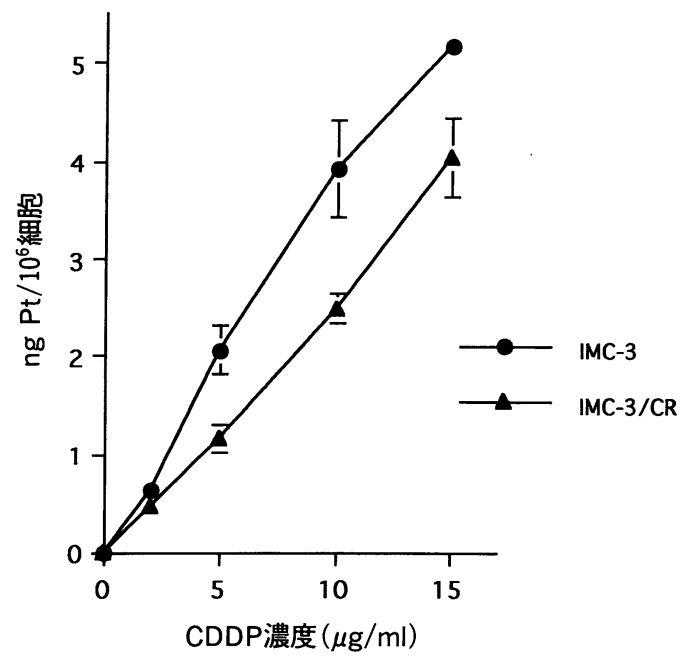

図 2 CDDP 耐性株 (IMC-3/CR) に批ける CDDP 流入量 上顎扁平上皮癌 (IMC-3 ; 九大小宮山教授より授受) と比 較して Pt (白金)流入量(蓄積量)が低下している.

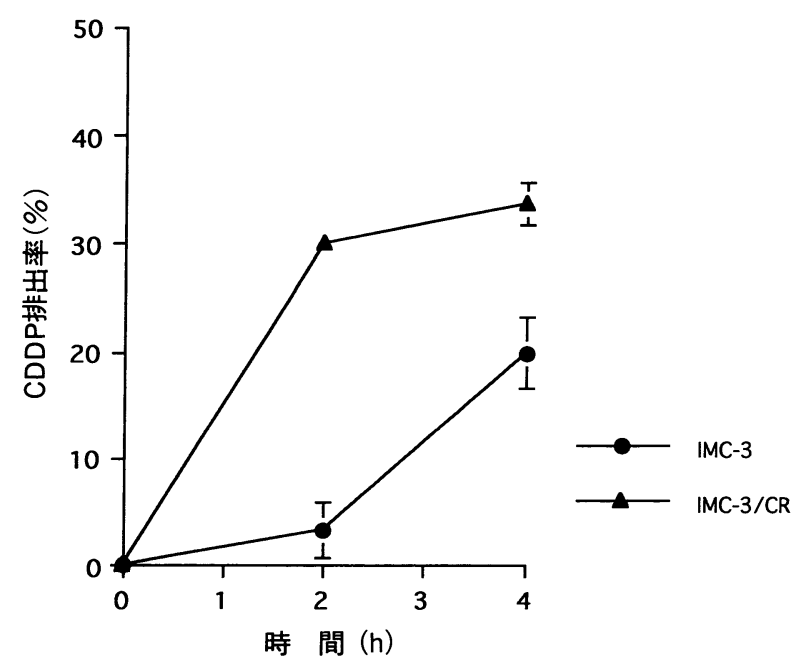

図 3 CDDP 耐性株 (IMC-3/CR) に抢ける CDDP 排出量

ル化剂をグルタチオン抱合によって解毒したり, アドリ アマイシンなどをグルタチオンペルオキシダーゼ活性に より解毒したりする。したがって，GSH の増加が薬剤 耐性機構になりらる。

われわれの施設でも28例の，外科的に切除した未治療 の頭頸部悪性腫瘍中の GSH を高速液体クロマトグラフ ィ法で測定し，ATP法による抗癌剤感受性と比較検討 した。
その結果, 細胞内 $\mathrm{GSH}$ を扁平上皮癌と甲状腺乳頭癌 と比較したところ, 扁平上皮癌の方が乳頭癌よりも有意 に高值を示した(図 4 ).

また，抗癌剤感受性との相関関係を調べたところ，5$\mathrm{FU}$ ，ペプロマイシンでは関係がみられなかったが，扁 平上皮癌と CDDP とは相関関係がみられた。13例中, 8 例に拈いては特に強い相関関係がみられ, 細胞内の GSH 量増大とともに CDDP の感受性が低下した（図 5 ). すなわち, GSH 量と耐性が相関しない扁平上皮癌

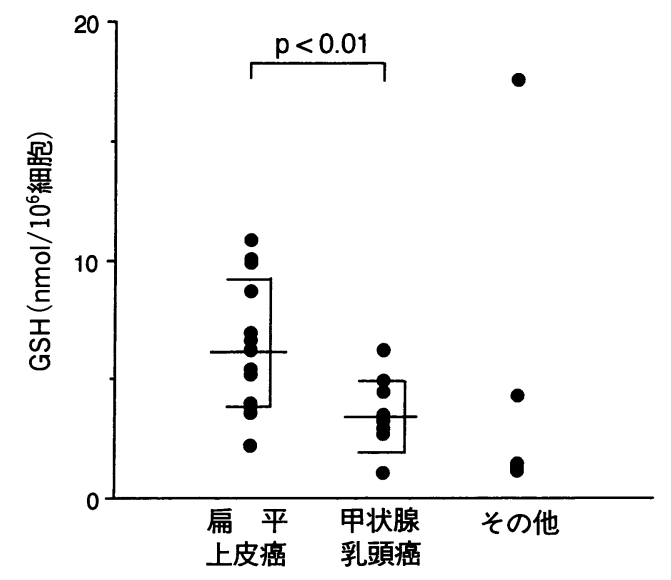

図4 病理組織別 GSH 含有量の比較

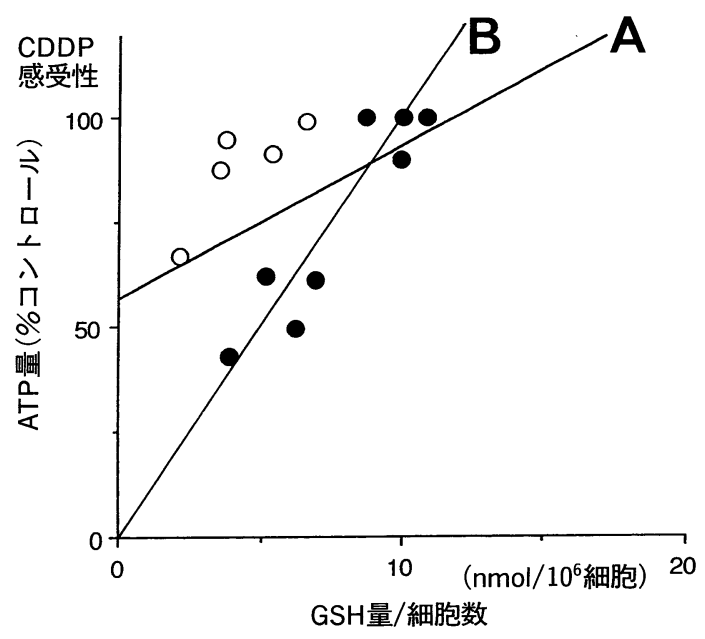

図 5 扁平上皮癌13例中の $\mathrm{GSH}$ 量と $\mathrm{CDDP}$ 感受性

ATP 量が少なくなるほど CDDP の感受性が高いことを 意味する. 扁平上皮癌13例では $\mathrm{A}(\mathrm{r}=0.55)$ のごとく, $\mathrm{GSH}$ 量と弱い相関があるが, 黒丸の 8 例でみると B $(\mathrm{r}=0.92)$ のごとく強い相関がある. 
も存在するといえる.

この GSH はブチオニンスルホキシミン(BSO)によっ て合成が阻害される。一方，オキソチアゾリジンカーボ キシレイト (OTZ) は GSH を増加させる.したがって， この GSH を低下させると抗癌剤の感受性が増強される ことが考えられ，ヒト卵巣癌細胞のアドリアマイシン， メルファラン, CDDP 耐性株に执いて, BSO Kよる感 受性増強が証明されている22).

3 ) 薬剤活性化酵素の低下

体内で活性化され抗癌性を発揮する 5-FU や葉酸代謝 拮抗剤の MTXなどは, それらの薬剂活性化酵素が低 下寸れば，制癌効果が減弱し耐性となる.

5-FUはそのままでは細胞毒性はない，uridine phosphorylase (UP) や uridine kinase (UK) などで活性化さ れて, FdUMP などの抗癌物質となる.5-FU 耐性機構 の 1 つとして, UP や UK の酵素活性の低下が知られて いる.

MTX は葉酸代謝を阻害し, 癌細胞の増殖を抑制する。 MTX はプリン, ピリミジン生成に必要なポリグルタミ ン酸誘導体と強い親和性をもち吸収されるが，耐性株で は，その誘導体の形成低下により MTX の吸収・蓄積 量が低下するといわれている.

以上のような耐性機構に対する有効な克服法の報告は まだない。

4 ）標的酵素活性の变化

カンプトテシン誘導体 (CPT-11) やエトポシドのどの トポイソメラーゼ阻害性抗癌剤に対する耐性機構がこの 代表といえる．DNAトポイソメラーゼ (Topo)にはI 型と II 型が存在し, DNA との結合, DNA 鎖の切断, 通過, 再結合によって DNA 高次構造変換を触媒してい る. I 型は ATP 非依存的に DNA 単鎖の切断と再結合 を，II 型は ATP 依存的に DNA 2 本鎖切断と再結合を 触媒している.

I 型酵素の阻害剤であるカンプトテシン誘導体の耐性 機構としては, I 型酵素の構造変異, 活性低下が報告さ れている、また，II型酵素の阻害剤であるエトポシド (VP-16)などでもその酵素活性の低下による効果減弱が 報告されている.

また，葉酸代謝拮抗剤の MTXのも51 つの耐性機 構として, 葉酸形成に重要な補酵素である dihydrofolate reductase (DHFR) の生成増加による薬㘊効果減弱が報 告されている.
しかし，以上の耐性機構に対する有効な対策も今のと ころ報告されていない。

5 ) DNA 修復系の克進

CDDP やアルキル化剤はDNA と結合することによ って細胞に致死的な障害をきたす。これらの薬剤に対す る耐性株では，DNA 修復活性が増加していると報告さ れている。この修復機構はまだ不明であるが，DNA と 選択的に結合する核蛋白が関与している可能性が指摘さ れている。

修復耐性機構は不明であるが，カフェインが DNA 修 復阻害剤として作用することが報告されている23)。また， 微小循環改善薬ペントキシフィリン(トレンタール®) と チオテパ併用臨床治験も行われている24).

6) アポトーシス耐性

細胞死にはネクローシスとアポトーシスとがある.ア ポトーシスは, 細胞容積が小さくなり, 核が濃縮し, 次 いで断片化する．最終的には細胞が分断化し，近隣の細 胞に貪食される，つまり，炎症反応を伴わない，他の細 胞にあまり悪影響を与えない死であるので, 癌化学療法 でもアポトーシスが誘導できれば好都合である。

アポトーシスを誘導できる抗癌剤として, トポイソメ ラーゼ阻害剤, アルキル化剂, 代謝拮抗剤, CDDP, チ ュブリン阻害剤などが報告されている25).

アポトーシスは種々の刺激により, 種々の細胞に誘導 される.アポトーシス関連分子も非常に多く報告されて いるが，現時点で明らかにアポトーシスの誘導において 重要と思われる経路を図 6 に示した。いずれにしても， 促進と抑制が微妙にからんでいるので，単純ではない。

一方, ヒ上単球性白血病 U937 細胞を変異処理し, そ の中からェトポシド, Ara-Cにより誘導されるアポトー シスに耐性な株 UK711 細胞が樹立されたが，これがア ドリアマイシン, マイトマイシンC，カンプトテシンに よるアポトーシスの誘導にも耐性であったとの報告があ る26).これが新しいアポトーシス耐性の存在を示唆する ものであり，多剤耐性の原因になりらることを示唆する ものである.

しかし，このアポトーシスの誘導とその耐性の克服は まだ緒についたばかりであり, 図6 からわかるように， 今後遺伝子治療としての展開が期待される.

7 ）まとめ

現時点での各種抗癌剤の耐性機構とその耐性克服の試 みを表 6 にまとめた。 


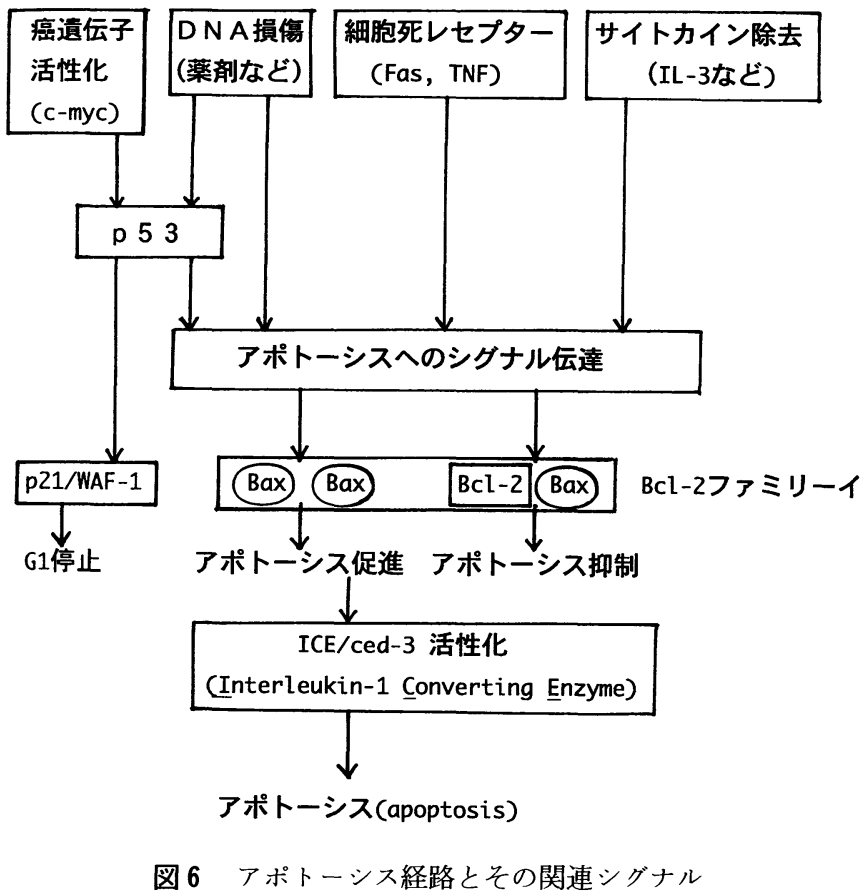

表 6 各種抗癌剂耐性機構とその克服剂

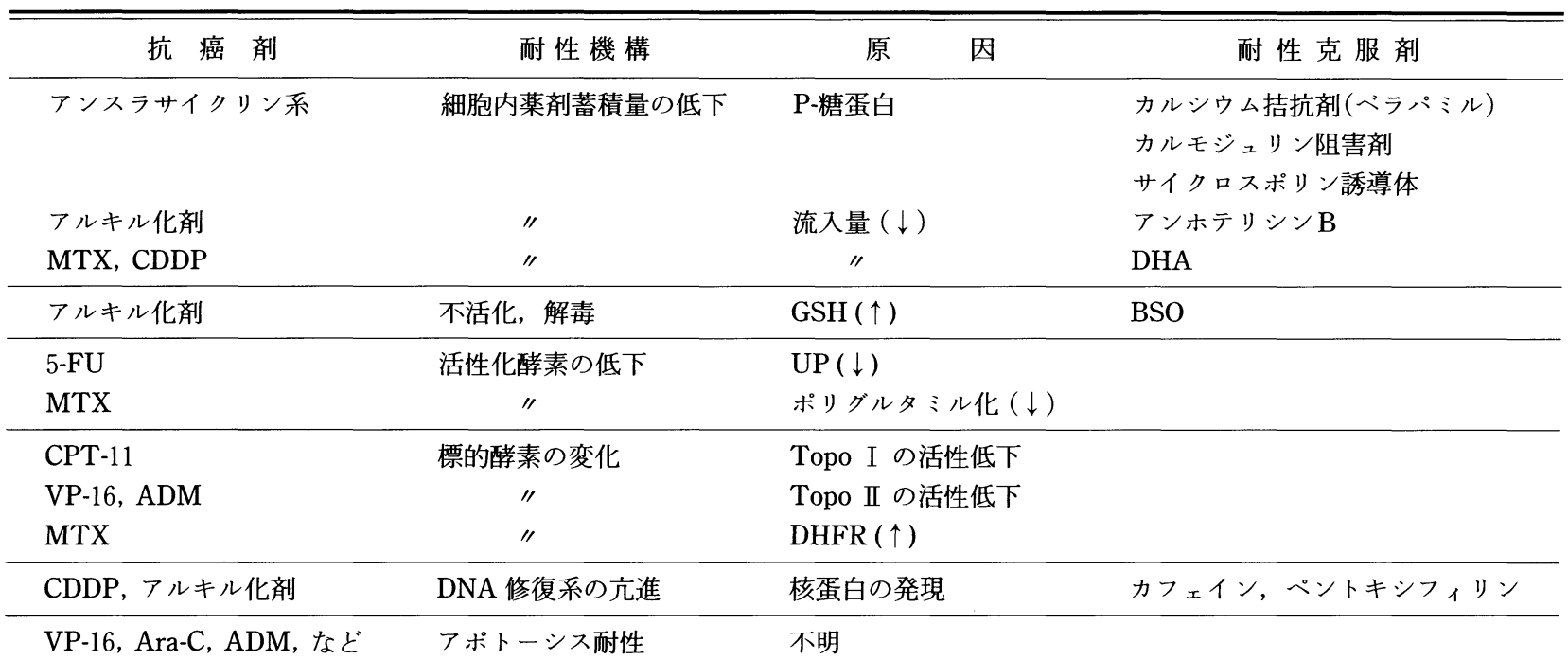

本論説の一部は, 基盤研究 (B) No. 07457397 によった.

\section{参考文献}

1) Hamburger AW and Salmon SE : Primary bioassay of human tumor stem cells. Science $197: 461 \sim 463,1977$.

2) Panje WR and McCormick KJ : Murine subrenal capsule assay; prediction of chemoresponsiveness in head and neck cancer. Laryngoscope $99: 41 \sim 49,1989$.

3 ) Bennett JA, Parnes SM and DeConti RC: Growth and chemosensitivity of human head and neck cancers implanted under the kidney capsule of cyclosporine-immunosuppressed mice. Ann Otol Rhinol Laryngol 98 : 455 $\sim 460,1989$.

4 ) Nakashima T, Uemura T, Maehara Y, et al : Succinate 
dehydrogenase inhibition test for evaluating head and neck tumors. Oncology $46: 162 \sim 168,1989$.

5 ) Saito H, Ohtsubo T, Fujieda S, et al : Chemosensitivity of head and neck cancer with rapid thymidine incorporation assay and its clinical application. Eur Arch Otorhinolaryngol $249:$ 400 403, 1992.

6) 田中信之, 斎藤 等 : 抗癌剂感受性試験 ATP 法の検討. 頭頸部腫瘍 $22 ： 476 \sim 481,1996$.

7 ) 斎藤 等 : 抗癌剂感受性試験と頭頸部癌. 耳鼻臨床 89 : $1526 \sim 1527,1996$.

8 ) 犬山征夫 : 頭頸部癌化学療法の歴史と現況. JOHNS 9 : 549 556, 1993.

9 ) Kartner N, Shales M, Riordan JR, et al : Daunorubicinresistant Chinese hamster ovary cells expressing multidrug reistance and a cell surface p-glycoprotein. Cancer Res 43 : 4413 4419, 1983.

10) Riordan JR, Duechars K, Kartner N, et al : Amplification of $\mathrm{P}$-glycoprotein genes in multidrug resistant mammalian cell lines. Nature $316: 817 \sim 819,1985$.

11) Goldstein LJ, Galski H, Fojo A, et al : Expression of a multidrug resistance gene in human cancers. J Natl Cancer Inst $81:$ 116 124, 1989.

12) Kelly DJ, Pavelic ZP, Gapany M, et al : Detection of Pglycoprotein in squamous cell carcinoma in the head and neck. Arch Otolaryngol Head Neck Surg 119 : 411 414, 1993.

13) Pavelic ZP, Reising J, Pavelic L, et al : Detection of pglycoprotein with four monoclonal antibodies in normal and tumor tissues. Arch Otolaryngol Head Neck Surg $119: 753 \sim 757,1993$.

14）都築秀明, 斎藤 等, 大坪俊雄, 他 : 頭頸部腫瘍における $\mathrm{P}$-糖蛋白の発現の検討(第二報). 頭頸部腫瘍 $22: 1 \sim 6$, 1996.

15) Tsuruo $T$, Iida $H$, Tsukagoshi $S$, et al : Overcoming of vincristine resistance in $\mathrm{P} 388$ leukemia in vivo and in vitro through enhanced cytotoxicity of vincristin and vinblastine by verapamil. Cancer Res $41: 1967 \sim 1972,1981$.

16) Schlemmer SR, Yang $\mathrm{CH}$ and Sirotnak FM : Functional modulation of multidrug resistance-related P-glycoprotein by Ca (2+)-calmodulin. J Biol Chem $270: 11040 \sim 11042$, 1995.
17) Miller TP, Grogan TM, Dalton WS, et al : P-glycoprotein expression in malignant lymphoma and reversal of clinical drug resistance with chemotherapy plus high-dose verapamil. J Clin Oncol $9: 17 \sim 24,1991$.

18) Twentyman $P R$ : Cyclosporine as drug resistance modifiers. Biochem Pharmacol 43 : 109 117, 1992.

19) Yahanda AM, Adler KM, Fisher GA, et al : Phase I trial of etoposide with cyclosporine as a modulator of multidrug resistance. J Clin Oncol 10 : 1624 1634, 1992.

20) Presant CA, Multhauf $P$ and Metter $G$ : Reversal of cancer chemotherapeutic resistance by amphotericin B ; a broad phase I-II pilot study. Eur J Clin Oncol 32 : 683 687, 1987.

21) Guffy MM, North JA and Burns CP : Effect of cellular fatty acid alteration on adriamycin sensitivity in cultured $\mathrm{L}$ 1210 murine leukemia cells. Cancer Res $44: 1863 \sim 1866$, 1984.

22) Hamilton TC, Winker MA, Louie KG, et al : Augmentation of adriamycin, melphalan, and cisplatin cytotoxicity in drug-resistant and -sensitive human ovarian carcinoma cell lines by buthionine sulfoxine mediated glutathione depletion. Biochem Pharmacol 34 : 2583 2586, 1985.

23) Dougherty JB, Kelsen D, Kemeny N, et al : Advanced pancreatic cancer; a phase I-II trial of cisplatin, high-dose cytarabine, and caffeine. J Natl Cancer Inst 81 : 1735 1738, 1989.

24) Dezube BJ, Eder JP and Pardee AB : Phase I trial of escalating pentoxifyline dose with constant dose thiotepa. Cancer Res $50: 6806 \sim 6810,1990$.

25) Sugimoto $C$, Matsukawa $S$, Fujieda $S$, et al : Involvement of intracellular glutathione in induction of apotosis by cisplatin in a human pharyngeal carcinoma cell line. Anticancer Res $116: 675 \sim 680,1996$.

26) Kataoka S, Naito M, Tomida A, et al : Resistance to anticancer agent-induced apotosis in a mutant of human myeloid leukemia U937 cells. Exp Cell Res 215 : 199 205, 1994.

\footnotetext{
別刷請求先 : 斎藤 等 $\left(\begin{array}{l}\text { 福 } 910-11 \text { 福井県吉田郡松岡町下学耳合月 } 23 \\ \text { 福咽喉科学教室 }\end{array}\right)$
} 